\title{
Consequences of plant phenolic compounds for productivity and health of ruminants
}

\author{
Garry C. Waghorn* and Warren C. McNabb \\ Nutrition and Behaviour, AgResearch, Grasslands Research Centre, Private Bag 11008, Palmerston North, New Zealand
}

\begin{abstract}
Plant phenolic compounds are diverse in structure but are characterised by hydroxylated aromatic rings (e.g. flavan-3-ols). They are categorised as secondary metabolites, and their function in plants is often poorly understood. Many plant phenolic compounds are polymerised into larger molecules such as the proanthocyanidins (PA; condensed tannins) and lignins. Only the lignins, PA, oestrogenic compounds and hydrolysable tannins will be considered here. Lignins slow the physical and microbial degradation of ingested feed, because of resilient covalent bonding with hemicellulose and cellulose, rather than any direct effects on the rumen per se. The PA are prevalent in browse and are expressed in the foliage of some legumes (e.g. Lotus spp.), but rarely in grasses. They reduce the nutritive value of poor-quality diets, but can also have substantial benefits for ruminant productivity and health when improved temperate forages are fed. Beneficial effects are dependent on the chemical and physical structure, and concentration of the PA in the diet, but they have been shown to improve live-weight gain, milk yield and protein concentration, and ovulation rate. They prevent bloat in cattle, reduce gastrointestinal nematode numbers, flystrike and $\mathrm{CH}_{4}$ production. Some phenolic compounds (e.g. coumestans) cause temporary infertility, whilst those produced by Fusarium fungi found in pasture, silage or stored grains can cause permanent infertility. The HT may be toxic because products of their metabolism can cause liver damage and other metabolic disorders.
\end{abstract}

Plant phenolic compounds: Proanthocyanidins: Ruminant production

\section{Lignin}

Forages and grain-based diets have similar energy contents, yet productivity of ruminants fed grains is often twice that from good-quality forages. The principal difference between grains and forages is the presence of lignified cell walls that account for $300-800 \mathrm{~g} / \mathrm{kg}$ forage DM. Cell walls are the dominant feed fraction for grazing ruminants. They comprise mainly cellulose and hemicellulose, and in legumes pectin, all of which are rapidly and extensively degraded by rumen microflora when lignin is not present. Acid-detergent lignin comprises only $20-50 \mathrm{~g} / \mathrm{kg}$ cell wall in temperate grasses (Jung et al. 1997), with generally higher concentrations in legume stems. Lignification in forages causes substantial reductions in the rate and extent of cell-wall degradation and the nutritive value of that forage for ruminants.

\section{Lignin synthesis and structure}

Plant cells comprise a thin outer wall that is not lignified. An inner (secondary) cell wall develops once cell expansion is complete, and this wall thickens and is lignified to provide the strength necessary to maintain structure and function (Wilson, 1993; Wilson \& Hatfield, 1997). Lignification is initiated in the middle lamella or primary wall and spreads throughout the secondary wall. This process involves the oxidation of three primary cinnamyl alcohols (coniferyl, sinapyl and $p$-coumaryl alcohols) that are randomly condensed to yield large indigestible polymers (Jung, 1989; Hatfield et al. 1999).

The hydroxycinnamic acid units in the polymer are responsible for the linkages between lignin and hemicellulose in the cell wall. In general, $p$-coumaric acids esterify with the lignin, and ferulic acids esterify with hemicellulose, but cinnamic acids link lignin with cell-wall polysaccharides by ether and ester linkages.

Hatfield et al. (1999) suggest that the positioning of ferulates within the cell wall will influence the formation of cross-linkages between potentially-digestible fibre and lignin. Development of more-digestible (or more-rapidlydigested) forages through a combination of molecular and traditional plant breeding techniques will require a good understanding of processes controlling feruloylation. 
Research effort has generally been directed towards understanding lignification in grasses rather than legumes. This situation may have arisen as a result of the existence of brown-mid-rib mutants of maize, sorghum and millet, which have lower lignin and $p$-coumaric acid concentrations and higher digestibilities than conventional plants (Wilson \& Hatfield, 1997), or because legumes are perceived to be of high nutritive value relative to grasses so there is less need for modification. However, grazing ruminants are primarily dependent on grasses, even in temperate climates, with legumes providing a minor portion of their diet in most situations.

Grass nutritive value declines dramatically with the onset of flowering, reducing nutritive value and intake. The events associated with grass maturation include increasing proportions of stem and sheath at the expense of leaf, with associated increases in lignified sclerenchyma and vascular tissues. These tissues provide much of the structural support required by plants, and their relatively small cross-sectional area underestimates their contribution to the DM and cell-wall content. Wilson (1993) showed the cross-sectional area of sclerenchyma and vascular tissues in species of Lolium and sorghum accounted for $200-400 \mathrm{~g} / \mathrm{kg} \mathrm{DM}$ and $430-640 \mathrm{~g} / \mathrm{kg}$ cell wall. They form much of the elastic, yet recalcitrant, fibre remaining after digestion of grasses.

Attempts to quantify the importance of lignin concentration in maturing grass and comparisons between grasses and legumes have been made more difficult by variations in analytical procedures. Lignin concentration measured using the Klason method is three to four times higher than that obtained with the acid-detergent lignin method in grasses and 30-40\% higher with legumes (Hatfield et al. 1994; Jung et al. 1997). Lignin concentration measured by the two methods was strongly correlated for legumes $(r 0.63)$ and $\mathrm{C}_{3}$ grasses $(r 0 \cdot 70)$ but there was no relationship for $\mathrm{C}_{4}$ grasses $(P>0 \cdot 10)$. Jung et al. (1997) demonstrated inconsistencies in the relationship between DM and cell-wall digestibility and lignin concentration, despite numerous assertions that lignin concentration is inversely correlated with digestibility. Although Jung et al. (1997) have suggested that the Klason assay may be more appropriate than acid-detergent lignin for grasses, the typically high values for Klason lignin concentration obtained with this method (about $100 \mathrm{~g} / \mathrm{kg}$ DM) suggest a marked in vivo digestion of lignin constituents. Thus, the concept of Klason lignin indigestibility may need to be revisited. This implication is supported by work of Lowry et al. (1994), who showed that there was a substantial quantity of 'acid-detergent-dispersible lignin' released during the acid-detergent phase of extraction. This component was much larger for grasses (often exceeding acid-detergent lignin) than legumes.

\section{Lignin and forage digestion}

Understanding the importance of lignin and bound low-molecular-weight phenolic compounds is therefore restricted by analytical technique and exacerbated by inconsistent relationships between concentration and DM or neutral-detergent-fibre digestibility for legumes. The low-molecular-weight phenolic compounds responsible for linking core lignin with cell-wall polysaccharides are metabolised in the rumen for absorption and urinary excretion, principally as hippuric acid (Lowry et al. 1993). The ferulic and $p$-coumeric acids and their degradation products (e.g. 3-phenyl propanoic, cinnamic and benzoic acids) do not appear to have antimicrobial activity in vivo, but may reduce hepatic gluconeogenesis (Cremin et al. 1995) and can represent a major $\mathrm{N}$ loss to animals fed low-quality grasses.

The mechanism by which lignin reduces the rate and extent of fibre digestion appears to be mainly through physical obstruction to bacteria gaining access to cell walls rather than any chemical inhibition of this process. The surface area available for colonisation by fibrolytic bacteria affects the rate and extent of fibre digestion. These bacteria adhere to cell walls, but their access requires previous rupture of the cell and exposure of the cell lumen (Satter et al. 1999); this process is facilitated by chewing. Lignification increases the requirement for chewing in order to achieve the desired extent of cell rupture. In vitro systems (Grabber et al. 1998) have provided a clear demonstration that ferulate and $p$-coumaric acid cross-linkages reduce degradation rate, but the mechanisms have not been clearly defined. Although lignin is considered to be the principal factor responsible for differences in nutritive value of cellwall carbohydrates $v$. non-lignified carbohydrates (starch, pectin, organic acids and sugars) more typical of concentrate-based rations, there is a need to define the extent of cell rupture during chewing and its effect on the rate at which polysaccharide fractions of cell walls are degraded by adherent bacteria. Chewing during eating ruptured 60 and $80 \%$ of the cells from good-quality fresh perennial ryegrass (Lolium perenne) and lucerne (Medicago sativa) fed to cows (Waghorn et al. 1989), and maximum rates of cell-wall digestion are dependent on rupture of the remaining cells by rumination.

\section{Consequences of lignin for ruminants}

The New Zealand dairy industry is based on fresh ryegrassdominant pasture. Its focus has been to maximise the proportion of available pasture harvested and to minimise waste for maximum efficiency. This strategy has resulted in cows that eat a limited supply of grass-dominant pasture very rapidly and consume sheath and stem components in addition to leaf. Rapid consumption, brought about by competition for available feed, further reduces the extent of cell rupture by chewing, reducing initial rates of digestion, and contributes to a high bulk of low-energy-density forage in the rumen. The weight of rumen contents measured 3-5 h after feeding good-quality leafy ryegrass pasture to cows in mid lactation was $220 \mathrm{~g} / \mathrm{kg}$ live weight compared with $110-150 \mathrm{~g} / \mathrm{kg}$ live weight for cows fed forage-concentrate rations (Waghorn, 2002). The rumen contents of pasture-fed cows in mid lactation were $110-130 \mathrm{~g} \mathrm{DM} / \mathrm{kg}$ and comprised long (up to $100 \mathrm{~mm}$ ) intact and highly-compacted grass that has to be chewed to a particle size of $\leq 4 \mathrm{~mm}$ in length to pass out of the rumen. The large digesta mass is a barrier to further increases in production from pasture, and chewing (eating and rumination) is likely to be the principal factor limiting feed intake and animal performance. Total mixed rations used extensively in the northern hemisphere 
also include silages to maintain a stable fermentation, but these have been chopped to $10-20 \mathrm{~mm}$ in length. Chopped silages will provide some abrasion and may stimulate more salivation and buffering than long flaccid grass leaves. Chopping is one way of reducing the impact of lignification on cell-wall digestion.

The impact of lignification on the productivity and health of ruminants fed temperate forages has been exacerbated by the use of urea to boost grass growth at the expense of legumes. The impact of a grass diet has been made worse by selection of animals capable of high production under adequate feeding regimens, which are then fed forages. In New Zealand cows calve in spring so that peak lactation demands coincide with maximum grass growth, but a substantial body-weight loss occurs over the first 6 weeks of lactation, followed by a monthly decline in milk yield of about $8 \%$, compared with $4 \%$ with balanced energydense total mixed rations. This undernutrition is exacerbated about 10 weeks past calving when the grass flowers, with commensurate reductions in digestibility and voluntary feed intake. Cows frequently stop cycling and are in a state of semi-starvation, despite adequate feed availability.

This scenario is common worldwide, where reproductive failure is brought about by undernutrition. The undernutrition is affected to a large extent by phenolic acids and lignification of cell walls reducing the rate of digestion, and indicates the importance of these compounds for ruminant productivity. The situation is perhaps worst for dairy animals, where selection for milk production has exceeded our capacity to feed the animals in an economicallysustainable way. Excessive live-weight loss and reproductive failure through underfeeding should not be tolerated in affluent societies. Future research must continue to elucidate the functional chemistry around lignification and effects on digestion in vivo. Careful consideration should be given to claims that cell-wall fibre would have a similar nutritive value to that of starches and soluble carbohydrates if it were not for lignification; because these claims may be exaggerated. Emphasis must be placed on sclerenchyma and vascular tissues that are tough and can only be broken down by chewing, but yield minimal nutrients for the animal. A small reduction in DM digestibility (through a rapid clearance from the rumen) would be acceptable if intake could be elevated. If grasses could be selected to have leaves and stems that were brittle rather than soft and resilient, a more rapid passage through the gastrointestinal tract, albeit with a lower digestibility, may achieve substantial improvements in nutrition, with a lesser impact from lignification.

\section{Proanthocyanidins}

Proanthocyanidins (PA) comprise flavan-3-ol (catechin) units condensed into polymers through $\mathrm{C}-\mathrm{C}$ bonding. They yield anthocyanidins on heating in acid and are synonymous with the term 'condensed tannins', derived from the condensation of flavan-3-ol units and their capacity to bind with protein to preserve (tan) leather. PA are common in leaves of browse plants (>300 g/kg DM in some instances; Rittner \& Reed, 1992) and in seed coats, and are expressed in the foliage of some temperate legumes at lower concentrations $(\leq 100 \mathrm{~g} / \mathrm{kg} \mathrm{DM})$. They are usually absent or have very low concentrations in the foliage of grasses. In tropical species, especially browse, the PA are often accompanied by a wide range of secondary metabolites (Lowry et al. 1996), including toxins such as mimosine from Leucaena spp. The PA are confined to intracellular vacuoles and are essentially unreactive until released by cell rupture, resulting in extensive binding with proteins (plant, animal, microbial, salivary, enzymes etc).

Components of both PA and lignin originate from phenylalanine synthesised via the shikimate pathway, but the ' $A$ ' ring of flavan-3-ols is formed from a condensation of three units of acetate (Mueller-Harvey \& McAllen, 1992). The polymerisation of flavan-3-ols differs from core lignin, with the majority of $\mathrm{C}-\mathrm{C}$ bonds between the $\mathrm{C}-4$ and $\mathrm{C}-8$ positions. Condensation results in chain lengths varying from about two to twenty units, with some branching, and there are a wide variety of well-defined hydroxylation patterns at several positions on each monomer. This structural diversity within and between plant species (Mueller-Harvey \& McAllen, 1992; Foo et al. 1996, 1997) accounts for the variation in biological activity.

\section{Tropical forages}

In tropical environments PA are almost always considered anti-nutritional, with research programmes identifying low PA accessions of tree fodder (see Waghorn et al. 1999b) and management to reduce the impact of dietary PA. Options include drying before feeding, diluting browse with grasses and occasionally giving animals polyethylene glycol, which binds to, and deactivates, the PA if sufficient is given. Much of the toxicity is due to PA in leaves that are selected by ruminants because they are more succulent and have a higher $\mathrm{N}$ content than tropical grasses; however, the PA bind with $\mathrm{N}$ and reduce its availability for both the microflora and the host ruminant. PA are indiscriminate in the protein to which they bind and easily create a protein $(\mathrm{N})$ deficiency, especially when poor-quality grasses make up a substantial portion of the diet (Waghorn et al. 1999b). Anti-nutritional effects are often exacerbated by other toxic components in tropical forages (Lowry et al. 1996), and their nutritive value cannot be predicted simply from neutral-detergent fibre, $\mathrm{N}$ and PA content (Rittner \& Reed, 1992).

The PA in tropical forages may benefit plant growth by reducing rates of mineralisation (release) into the soil from leaf litter (Palm \& Sanches, 1991), and probably from animal faeces. PA divert $\mathrm{N}$ from urine to faeces during digestion and lessen $\mathrm{N}$ losses from urinary volatilisation. The benefits of PA for $\mathrm{N}$ conservation may provide a better explanation of the presence of PA in plants than theories suggesting protection from herbivory, insect or microbial predation. Ruminants readily select plant components containing high PA concentrations in preference to stems or grasses, so that theory seems to be mainly speculation. Protection against insects and microbial predation would only be achieved by direct contact with the PA that is sequestered in plant vacuoles. 


\section{Temperate forages}

Most research has been directed towards PA in temperate forages because these can have substantial benefits for ruminant health and productivity. Extensive efforts are in place to select or express PA in high-value legumes such as white clover (Trifolium repens) or lucerne, but ironically some of the drive for PA expression is as a result of excessive concentrations of readily-degradable protein in these species resulting from earlier selections. These programmes are directed towards PA expression rather than synthesis, because many legumes do express PA in seed coats or in flowers (e.g. white clover). Successful foliar expression has not been achieved, to our knowledge, in such species, despite initial achievements in lucerne (Larkin et al. 1999) and a good knowledge of biosynthetic pathways for PA.

Contrast this knowledge with the temperate legumes that express PA in foliage: lotus, sainfoin (Onobrychus viciifolia), sulla (Hedysarum coronarium) and other species such as dock (Rumex obtusifolia), Serecia lespedezia ( $L$. cuneata) and Dorycnium rectum. These forages perform well under conditions of average or poor soil fertility, and can be tolerant of acid soils (lotuses), but they have not received any extensive research inputs.

The benefits of PA from temperate forages for sheep and cattle have been summarised in Table 1 . The value of lotus for bloat prevention has been known since 1716 (Beddows, 1956). More recent research has defined some benefits of PA for improved live-weight gain (Waghorn et al. 1999b), increased protein concentration in milk from sheep (Wang et al. 1996a) and cows (Harris et al. 1998; Woodward et al. 1999) and improved lambing percentage (Min et al. 1999). Other benefits for animal health include reductions in intestinal nematode numbers (Niezen et al. 1995) and their impact on sheep (Robertson et al. 1995), reductions in the incidence of flystrike (Leathwick \& Atkinson, 1995) and

Table 1. Benefits and costs attributable to proanthocyanidins in forages fed to ruminants

Benefits
Improved live-weight gain; no effect on carcass composition
Improved wool growth
Increased lambing percentage (ovulation rate)
Increased milk production in sheep and cows
Increased protein concentration in milk from sheep and cows
Reduced flystrike in sheep
Reduced dags* on sheep
Reduction in helminth intestinal parasite burdens in sheep
Improved tolerance of intestinal worm burdens in sheep and deer
Prevention of bloat in cattle
Lowered $\mathrm{CH}_{4}$ production
Problems
Benefits do not apply to all sources of PA; Lotus corniculatus
provides consistent benefits for production and sulla
(Hedysarum coronarium) reduces gastrointestinal parasite
numbers
High concentrations and astringent PA reduce live-weight gain
and productivity and can cause deaths
Lower voluntary feed intake can occur with some sources of PA
Lower nutritive value of other dietary constituents may occur

*Adhesion of faeces to wool. adhesion of faeces to wool (dags). Recently, Waghorn et al. (2002b) have shown that PA were able to reduce methanogenesis from sheep. There is good potential to reduce $\mathrm{N}_{2} 0$ losses from manure and urine patches by redirecting $\mathrm{N}$ away from urine and binding it with PA in faeces. These opportunities offer an important mechanism for improving the sustainability of temperate pastoral farming where there is both high productivity and extensive fertiliser application.

Mechanisms by which PA affect these responses are reasonably well understood (at least conceptually) for nutritive value, milk composition, lambing percentage and bloat, but impacts on intestinal nematodes, flystrike and methanogenesis are speculative. Responses to PA are complicated by demonstrations that the type(s) of PA may be more important than the concentration in the diet (for example, see Waghorn \& Shelton, 1997; Aerts et al. 1999). PA structure has been defined for species of lotus (Foo et al. 1996, 1997) and, although heterogeneity precludes simple descriptions, it also offers opportunities to identify highlyactive fractions. A brief overview of PA concentrations and mode of action during digestion will be followed by a synopsis of their benefits to animal health and productivity.

\section{How much proanthocyanidins in the diet?}

Nutritionists and researchers continue to define dietary PA in terms of concentration, as well as either beneficial or detrimental impacts on performance. However, the value of PA is dependent on the analytical technique, the purpose for which it is intended and the animal species.

There are several analytical techniques available for measuring concentration, including butanol- $\mathrm{HCl}$ sequential extraction, dimethylaminocinnamaldehyde- $\mathrm{HCl}$, acidified vanillin, protein aggregation and HPLC separation. These methods can yield quite different results (for example, see Terrill et al. 1992). The 'free, protein-bound and fibrebound' PA from butanol- $\mathrm{HCl}$ extractions also pose risks for over-interpretation of values because the proportions of each are a function of total PA and available (mainly protein) binding sites. The only meaningful interpretation of these ratios is that a high proportion of 'free' PA suggests good opportunities for binding to other dietary constituents. A high protein concentration will reduce the proportion of free PA, and ratios are affected by drying technique, with oven-drying leading to a lower 'free' and higher 'bound' PA relative to freeze-drying. Drying reduces the anti-nutritional impacts of high PA concentrations in tropical forages. Values presented here are based on freeze-dried forage and total PA determined by the butanol- $\mathrm{HCl}$ method.

Variations attributable to the type of PA offer opportunities for future exploitation to improve animal and human health. The importance of the chemical composition of PA was illustrated by Waghorn \& Shelton (1997). The PA in Lotus pedunculatus were shown to be more potent than those in Lotus corniculatus, even when dilutions with grass lowered the dietary PA concentration below that for L. corniculatus fed alone. Trials with sainfoin containing about $80 \mathrm{~g} \mathrm{PA} / \mathrm{kg}$ diet have demonstrated that this forage has high nutritive value for sheep, whereas diets including carob (Ceratonia silique) pulp and containing only $25 \mathrm{~g} \mathrm{PA} / \mathrm{kg}$ severely depressed growth rates (Priolo et al. 2000). 
Low concentrations of PA (e.g. $10 \mathrm{~g} / \mathrm{kg}$ DM) cause intestinal damage in chickens and $30-40 \mathrm{~g} \mathrm{PA} / \mathrm{kg}$ lower amino acid absorption and performance in pigs (see Waghorn, 1996). Ruminants are tolerant of dietary PA and, although comparative trials between species do not appear to have been undertaken, there is evidence that giraffes (Giraffa camelopardalis), goats and deer are more tolerant of dietary PA than sheep or cattle because their high-proline salivary proteins reduce its effect in the rumen. However, an 'optimal' type or concentration of PA will vary with the time over which it is fed and whether the PA are intended to benefit nutrition or welfare.

\section{Proanthocyanidins and digestion}

Chewing during eating initiates binding between PA and plant and salivary proteins, causing protein aggregation in place of the normal solubilisation.

Aside from reductions in protein solubility and degradation rate in vivo and in vitro, the mechanisms by which PA behave in the rumen are poorly understood. The consequences are clear, especially the increased outflow of undegraded plant protein to the intestines $(\mathrm{McNabb}$ et al. 1996), substantial reductions in rumen $\mathrm{NH}_{3}$ concentration and lesser effects on microbial outflow. Lowry et al. (1996) summarised research showing that PA derived from several forages varied in their inhibition of cellulose degradation, and the growth of several bacterial species were inhibited by PA whilst others appeared unaffected.

Some evidence suggests higher-molecular-weight PA will be more astringent than low-molecular-weight PA, and that prodelphinidins will be more inhibitory than procyanidins, but it is unclear whether the principal effects are the result of inhibition of extracellular enzymes or deprivation of substrate (Scalbert, 1991). The size of PA precludes movement across microbial membranes, but glycoprotein secretion is induced in some bacteria to reduce the impact of PA. Similar responses are seen with increased goblet cell numbers and mucus secretion in the presence of PA, especially in the chicken (Ortiz et al. 1994). Monomeric flavanols inhibit bacterial growth, but the majority of those present in plants are polymerised. Rumen digesta obtained from African animals accustomed to browse, and sheep, did not show any microbial adaptation for increased tolerance or metabolism of PA (Jones et al. 2001).

Dietary PA always increase the proportion of undegraded plant protein passing from the rumen to the acidic abomasum. In contrast to laboratory studies, our observations suggest only limited dissociation of PA from protein in the abomasum, or a very rapid re-association in the small intestine, because PA inhibit amino acid absorption. When sheep were fed L. corniculatus, containing 'beneficial' PA, Wang et al. (1996b) showed that amino acid absorption extended over the entire length of the small intestine, in contrast to the majority of absorption in the proximal third when PA were removed by polyethylene glycol. The PA in L. corniculatus do not reduce the fractional absorption of essential amino acids, so the benefits of an increased rumen protein outflow are secured by an increased amino acid absorption. In contrast, in sheep fed $L$. pedunculatus the fractional absorption of amino acids was substantially reduced by PA, so that they did not benefit from the increased rumen outflow (Waghorn et al. 1999b). The cause of reduced absorption in the presence of PA from L. pedunculatus is not clear. Proteolytic enzyme activity is reduced by PA, but substantial activity remains (Waghorn, unpublished results), and the histological damage reported by Brooker et al. (2000) in sheep fed mulga (Acacia aneura) containing $>100 \mathrm{~g} \mathrm{PA} / \mathrm{kg}$ was not observed by Walton et al. (2002) in sheep fed L. pedunculatus. The PA are modified during digestion, but $96 \%$ of the carbon from ${ }^{14} \mathrm{C}$-labelled PA were recovered in faeces even though colorimetric analyses suggested a substantial loss during digestion (Terrill et al. 1994).

\section{Effects of proanthocyanidins on production}

Responses to dietary PA have been evaluated by comparing performance against similar forages that do not contain PA (e.g. lotus $v$. white clover or lucerne) or by feeding the forage with and without administration of polyethylene glycol to remove the effects of PA. Polyethylene glycol may be given with feed, water, as an oral drench or via intra-rumen infusions with fistulated animals. Response measurements have included live-weight gain, composition of gain, milk production and composition, wool growth and reproductive performance. It is important to note that a small or negative response to PA in temperate forages does not imply poor performance. The lotuses, sulla and sainfoin generally have a high feeding value irrespective of their PA content.

Responses to PA in a wide range of temperate and tropical diets reported before 1997 have been summarised by Waghorn et al. (1999b). The PA in L. corniculatus when fed alone always benefited performance, with lesser responses as the proportion in the diet diminished. In contrast, the PA in L. pedunculatus when fed alone did not benefit performance and sometimes had substantial negative impacts, especially with prolonged feeding. Limited trials in which sulla or sainfoin were fed to sheep nearly always showed a positive response to PA, but when sulla was fed for a prolonged period (17 weeks) in one experiment the PA reduced both daily gain and carcass yield (Douglas et al. 1999). Responses to PA in tropical browse, e.g. species of Acacias, Ceratonia, Calliandra, Sesbania, Glicicidia and Lucaena, are nearly always negative when fed to either sheep or goats. Performance has been improved by feeding accessions with lower PA concentrations, and feeding them with pasture improved performance relative to pasture alone.

Recent research in New Zealand has focused on L. corniculatus or sulla as forages for sheep and dairy cows. Both forages require specialist management, and once mastered have enabled good productivity under commercial and research environments. Sheep fed lotus have substantially improved productivity relative to pasture and, although PA has improved lambing percentage, it does not always improve wool growth (Min et al. 1999). Sulla also has excellent potential for sheep, but the PA concentration ranges from 20 to $110 \mathrm{~g} / \mathrm{kg} \mathrm{DM}$ (Waghorn, unpublished results), so feeding systems must accommodate this variation. Sulla is high yielding and promotes high rumen 


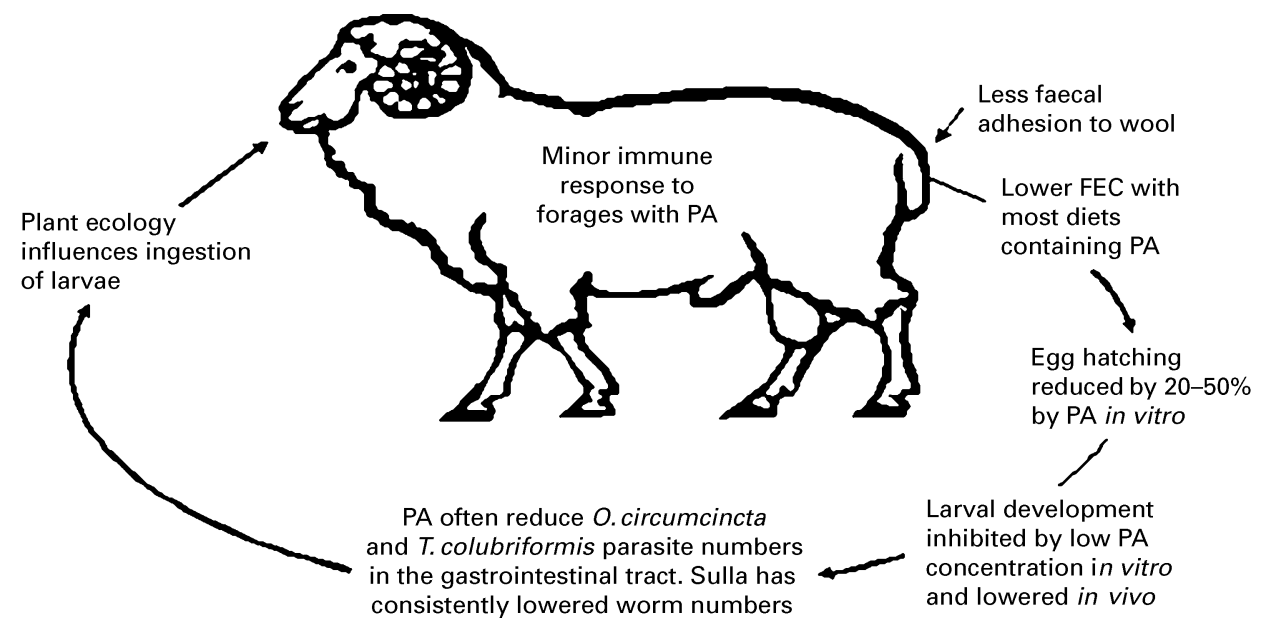

Fig. 1. Proanthocyanidins $(P A)$ are able to influence gastrointestinal parasitism at several stages of the life cycle in sheep. Sulla, Hedysarum coronarium; O. circumcincta, Ostertagia circumcincta; T. colubriformis; Trichostrongylus colubriformis; FEC, faecal egg count. Data are based on in vitro (Molan et al. 2000, 2002) and in vivo (Niezen et al. 1995, 2002a, b; Robertson et al. 1995) observations.

propionate:acetate with relatively low rumen $\mathrm{NH}_{3}$ concentrations, and has been evaluated as a complementary diet with lucerne, white clover and pasture (Burke et al. 2002).

These forages have been fed either fresh or ensiled to dairy cows to complement pasture. The PA in fresh L. corniculatus improved the efficiency of feed utilisation and increased milk yield by about $10 \%$, with marked increases in milk protein concentration relative to white clover (Harris et al. 1998). The PA reduced milk fat concentration (Woodward et al. 1999), but to a lesser extent than with sheep (Wang et al. 1996a).

The benefits of PA in temperate forages are probably due to an increased absorption of essential amino acids from the intestine, with a reduction in $\mathrm{NH}_{3}$ absorption lessening the need for metabolism to urea. No marked changes have been reported in the proportions of the major volatile fatty acids produced in the rumen of animals fed these forages. Like lignin, PA are not digested and their presence reduces the proportion of a diet available for utilisation; an optimal PA would be highly effective and present in a low concentration. Although fibre digestibility is not usually reduced by PA from temperate forages, the rate of digestion can be slower, and this finding suggests longer rumen retention times or increased rumen pool size. Any reduction in feed intake attributable to PA will limit their usefulness for ruminants.

Reductions in $\mathrm{CH}_{4}$ production per unit DM intake attributable to PA (Waghorn et al. 2002b) have been reported for sheep fed L. pedunculatus, and this outcome offers a route for lowering greenhouse gas emissions from agriculture. The reduction in that trial was $16 \%$ and the PA concentration was $8 \mathrm{~g} / \mathrm{kg}$ DM. Lowering energy losses to $\mathrm{CH}_{4}$ in this way may spare additional energy for production if the $\mathrm{H}$ associated with $\mathrm{CH}_{4}$ is directed towards acetate synthesis. This latter effect has yet to be established.

\section{Proanthocyanidins and animal health}

There are several avenues by which PA can improve ruminant health and welfare: improved nutrition in some instances; bloat prevention; reduction in dags and flystrike in sheep; reduction in gastrointestinal worm numbers and their impact on livestock (Fig. 1).

The ability of PA to reduce the incidence and severity of bloat is well known. The propensity for lucerne and white clover to cause bloat has been a major incentive for trying to express PA in their foliage. Bloat is often associated with feeding lush highly-fermentable protein-rich forages to ruminants. The rapid disintegration of these legumes entraps gases from fermentation in a proteinaceous stable foam and results in the aeration of rumen fluid. The aggregation of soluble proteins with PA interferes with the formation of a stable foam and is often sufficient to prevent bloat or reduce its severity. The concentration of dietary PA needed to achieve bloat protection has been extrapolated as $5 \mathrm{~g} / \mathrm{kg}$ $\mathrm{DM}$, but this concentration has not been rigorously tested and will depend on the nutrition, hunger, rate of eating and dietary composition.

The importance of bloat to dairy farmers should not be underestimated, partly because of its intermittent occurrence and either their inability or reluctance to treat all cows with anti-bloat agents when bloat is infrequent. Current research with sainfoin in Canada (McMahon et al. 2000) and with prolific-flowering white clover to increase sward PA concentrations in New Zealand is driven by the need to reduce the incidence of bloat.

Improved pastures have resulted in a rapid passage of digesta through the large intestine, perhaps enhanced by fungal endophytes in grasses, to produce loose (nonpelleted) faeces in sheep. These faeces adhere to the wool (dags) and are a major attractant to several species of fly (e.g. Lucilia cuprina) that deposit eggs, often in the wool adjacent to the adhered faeces. The development of their 
maggots is a serious issue for sheep husbandry (Waghorn et al. 1999a). Diets containing PA usually result in pelleted faeces that do not adhere to wool, reducing their attractiveness to flies. However, findings of Leathwick \& Atkinson (1995) from trials comparing L. corniculatus with pasture suggested that the low incidence of flystrike in sheep grazing this forage was also attributable to some other factor(s). These forages have important implications for the ethics and welfare of farmed livestock.

The recent surge in research concerning PA and gastrointestinal parasites is probably due to increasing incidence of resistance to the three classes of proprietary drenches currently available. Our interest arose from suggestions that polyphenols from raspberry canes reduced the incidence of soil nematodes when they were incorporated into the soil (Taylor \& Murant, 1966) and by studies showing that lambs fed sulla had much lower numbers of gastrointestinal parasites than lambs fed lucerne (Niezen et al. 1995). The most impressive aspect of this study was the relatively good performance of parasitised lambs fed sulla. Several other forages were also compared to determine performance in the face of Ostertagia circumcincta and Trichostrongylus colubriformis worm burdens (Robertson et al. 1995). Only sulla reduced worm numbers, but $L$. corniculatus and L. pedunculatus supported very good animal performance in the presence of substantial worm numbers.

Fieldwork was accompanied by laboratory assays of larval mobility (Molan et al. 2000), egg hatching and larval development (Molan et al. 2002). Egg hatching was reduced but not prevented by PA; however, development to L3 larvae was severely reduced by concentrations of $200 \mu \mathrm{g}$ $\mathrm{PA} / \mathrm{ml}$. The ranking of forages in terms of laboratory inhibition have not matched field observations of faecal egg count or nematode numbers, and sheep do produce viable nematode eggs when grazed on forages containing PA (Niezen et al. 2002b). Recovery of eggs and larvae from faeces of sheep fed lucerne, white clover and diets with PA did demonstrate marked effects of diet type, but there was no evidence of complete suppression of development, as suggested by reports of in vitro results. The concentration of PA (albeit modified during digestion) in faeces is typically $60-200 \mathrm{~g} / \mathrm{kg}$ faecal DM, several orders of magnitude above that which was effective in vitro.

Commercial sources of PA, especially Quebracho extract, have been extensively evaluated in sheep by Athanasiadou et al. $(2000,2001)$ who found similar results to those for forages containing about $50 \mathrm{~g} \mathrm{PA} / \mathrm{kg} \mathrm{DM}$. Parasite numbers were reduced, but effects were variable and never $100 \%$. Similar benefits of PA have been reported with farmed deer (Hoskin et al. 2000), with PA reducing larvae development in vitro (Molan et al. 2002). There does not appear to be any research concerning the impact of PA on cattle parasites.

In summary, PA are able to reduce the extent of intestinal parasite infection in sheep and deer. The impact is dependent on the source of PA and, although the mechanism of action has not been defined, most evidence suggests a direct effect rather than a nutritional compensation or immune response. Reduced viability of eggs and larvae from animals grazing diets with $\mathrm{PA}$ will reduce the incidence of re-infection (Fig. 1). Current limitations to this route for parasite control are the relatively large quantities of
PA required to achieve meaningful effects and limited understanding of the mechanisms of action. PA are unlikely to achieve parasite control similar to that achieved with proprietary drenches, but could provide substantial benefits when combined with other techniques, e.g. strategic grazing and occasional use of proprietary drenches or nematicidal fungi. It is worth remembering that ruminants grazing tropical browse can be heavily parasitised, despite high dietary PA concentrations.

\section{Hydrolysable tannins}

Hydrolysable tannins are present in oak (Quercus spp.), Acacia, Eucalypts and a range of browse and tree leaves. These leaves can form a major component of ruminant diets in Mediterranean and tropical regions where grasses are of poorer quality, especially during the dry season when the $\mathrm{N}$ content of grasses falls below $10 \mathrm{~g} / \mathrm{kg}$ DM and is not sufficient to sustain ruminants. Under these conditions ruminants become increasingly dependent on browse as a food and $\mathrm{N}$ source. The leaves and apices from these browse can contain up to about $200 \mathrm{~g}$ hydrolysable tannins $/ \mathrm{kg}$ DM, with total phenolic compounds $>500 \mathrm{~g} / \mathrm{kg}$ DM in some species (Reed 1995; Lowry et al. 1996). In contrast, temperate forages have negligible hydrolysable tannin concentrations.

Hydrolysable tannins are polyesters of phenolic acids or their derivatives with a polyalcohol core, usually glucose. Typical hydrolysable tannins are gallic acids or gallic acid dimers esterified to glucose to form pentagalloylglucose (gallotannin), similar to tannic acid. These simple structures are not common in plants, but are a basic structure from which more complex forms evolve through linkages between gallic units by a depside bond (ellagitannins), polymerisation and variations in both the phenolic group and core structure (Mueller-Harvey, 2001). Hydrolysable tannins are extremely diverse in nature, making accurate analyses for comparisons between forages difficult. Mueller-Harvey (2001) advocates the use of several assays to characterise tanniniferous feeds that usually express an array of phenolic compounds.

The location of hydrolysable tannins has been investigated in oak leaves in which both synthesis and deposition was adjacent to mesophyll cell walls, with no evidence of storage vacuoles (Grundhofer et al. 2001). The concentration of gallic acid was relatively constant in leaves throughout the growing season. Peak concentrations of galloylglucoses occurred about 3 months after leaf burst, after which they were oxidised to ellagitannins in summer and the hydrolysable tannins were degraded before senescence.

Although potentially toxic, most ruminants adapted to these types of diets do not demonstrate overt toxicity, and in some situations they may contribute to ruminants nutritional requirements. Lowry et al. (1996) reported that ruminants eating diets containing hydrolysable tannins reduced their urinary excretion of degradation products as they became accustomed to the toxins. They also provided evidence for degradation of the core of the molecule (glucose or quercetin) and microbial degradation of pyrogallol to phloroglucinol. This process would provide a possible route for utilisation of phenolic compounds to provide nutrients. Apart from rapid and extensive hydrolysis to the 
polyalcohol core and gallic acids, there does not appear to be any quantitative information on the extent to which gallic acid is metabolised to pyrogallol (Reed, 1995), or the relative absorption of these metabolites. They are absorbed from both the rumen and the intestine and may be conjugated to glucuronic acid after absorption.

Excessive consumption of forage containing hydrolysable tannins has led to liver and kidney lesions and death in sheep and cattle, usually 5-10d after initial excessive consumption; however, the actual toxic compound causing the damage is not known with certainty.

\section{Oestrogenic compounds}

A number of secondary metabolites containing phenolic groups are categorised on the basis of their effect on animals. These metabolites include oestrogenic compounds from clovers (isoflavones) and lucerne (coumestans) and Fusarium fungi associated with maize, small grains and pasture (zearalenones). The list could also include toxins associated with either primary photosensitisation or photosensitisation arising from liver damage (Cheeke, 1998).

These compounds are mentioned as an illustration of the diverse responses associated with these phenolic compounds, although their main activity is through oestrogenic effects. Plant selections have been undertaken to reduce the impact of phyto-oestrogens, especially on sheep reproduction, because consequences can be severe, with either temporary or permanent infertility (Adams, 1995). Isoflavones are synthesised from phenylalanine and resemble oestrodiol. The metabolites responsible for reducing fertility are associated mainly with subterranean (Trifolium subterraneum L.), red (Trifoliun pretense) and berseem clovers (Trifolium alexandrinum L.) and soyabeans, and include genistein, daidzein, biochaninA and formononetin. The isoflavone content may reach $50 \mathrm{~g} / \mathrm{kg}$ plant DM and after $7-10 \mathrm{~d}$ of adaptation sheep rumen microbes degrade genistein, biochaninA and daidzein to non-oestrogenic metabolites (including phenolic acid). Consequently, they have short-term effects on fertility. In contrast, formononetin is modified by the rumen microflora to equol, which is absorbed and is a potent oestrogen. Cattle appear less susceptible to formononetin than sheep because in cattle it is excreted rapidly. Isoflavone synthesis is heritable, and successful breeding programmes have reduced formononetin concentration in these forages whilst maintaining sufficient genistein or biochaninA, so that the plant remains competitive without causing reproductive problems (Waghorn et al. 2002a).

In contrast to isoflavones, coumestan concentration depends on environmental conditions, especially fungal and insect invasion. Concentrations are therefore determined by plant resistance to pathogens and by environmental conditions. Coumestans are synthesised from cinnamic acid and are expressed in lucerne, medicks (Medicago spp.), white clover and soyabeans. Coumestans are not substantially degraded in the rumen, so animals cannot adapt to their presence.

Zearalenone is a mycotoxin produced by Fusarium fungi that grow in maize and other grains or on dead plant material in pastures. Consumption of contaminated grain causes temporary infertility in cattle, and pasture concentrations exceeding about $1 \mathrm{mg}$ zeralanenone/kg DM have been associated with reduced lambing percentage in sheep. Zeralanenone is also used as a growth promotant with cattle.

\section{Summary}

Plant phenolic compounds impact on ruminant health, nutrition, performance and environmental sustainability. The diversity of phenolic compounds prevents a generalised synopsis of their effects; impact is influenced by the type, concentration and astringency of the dietary phenolic compound, animal physiological status, sex, exposure to pathogens, anticipated productive performance and environmental conditions.

Lignin is non-toxic and ubiquitous, and its importance is determined by the amount of grass in the ruminant diet. Agronomic selections for improved nutritive value must focus on rates of fibre breakage and clearance from the rumen rather than digestibility per se, and improved feeding value will only be achieved when lignin-fibre relationships are properly elucidated.

PA have received extensive scientific attention because they can either provide substantial benefits to nutrition or be detrimental to animal performance. However, the impetus for current research is based on their potential for lessening the impact of intestinal parasitism and potential use in place of antibiotics. The PA reduce rumen proteolysis and increase bypass protein reaching the intestine, but these benefits can be countered by lower fractional absorption of amino acids, reduced intake and lower digestibility. Effects of PA depend on dietary concentration, astringency and type. Future research should identify optimal structures for expression in the foliage of high-quality feedstuffs to be offered alone or with grass. The feeding system will influence the choice of type and concentration of PA in the diet. Ideal recipient plants could include clovers or lucerne, although greatest benefits would be derived from expression in grasses. Future research will be increasingly driven by the ability of dietary $\mathrm{PA}$ to divert $\mathrm{N}$ away from urine to faeces and reduce leachates, and to reduce $\mathrm{CH}_{4}$ emissions from ruminants.

Despite the severe impact of PA and hydrolysable tannins in tropical browse, global distribution of wealth, intensive livestock production and research facilities are likely to remain focused on beneficial aspects of PA for temperate agriculture. Hydrolysable tannins have been characterised and the many structural variants indicated, but there is a paucity of information concerning digestion, absorption and impact on metabolism and productivity.

The wide-ranging effects of plant phenolic compounds, including oestrogenic compounds, offers a huge potential for capturing benefits from these secondary plant metabolites. Their structural diversity offers considerable opportunity for exploitation, and at the same time immense challenges for science.

\section{References}

Adams NR (1995) Detection of the effects of phytoestrogens in sheep and cattle. Journal of Animal Science 73, 1509-1515.

Aerts RJ, McNabb WC, Molan A, Brand A, Barry TN \& Peters JS (1999) Condensed tannins from Lotus corniculatus and Lotus 
pedunculatus exert different effects on the in vitro rumen degradation of ribulose-1,5-bisphosphate carboxylase/oxygenase (Rubisco) protein. Journal of the Science of Food and Agriculture 79, 79-85.

Athanasiadou S, Kyriazakis I, Jackson F \& Coop RL (2000) Consequences of long-term feeding with condensed tannins on sheep parasitised with Trichostrongylus colubriformis. International Journal for Parasitology 30, 1025-1033.

Athanasiadou S, Kyriazakis I, Jackson F \& Coop RL (2001) Direct anthelmintic effect of condensed tannins towards different gastrointestinal nematodes of sheep: in vitro and in vivo studies. Veterinary Parasitology 99, 205-219.

Beddows AR (1956) Observations on hoove, haven, blown or bloa4 taken from agricultural writings, 1716-1827. Journal of the Agricultural Society 33, 12-15.

Brooker JD, O'Donovan L, Skene IK \& Sellick G (2000) Mechanisms of tannin resistance and detoxification in the rumen. In Microbial Biosystems. New Frontiers, Proceedings of the 8th International Symposium on Microbial Ecology, pp. 409-417 [CR Bell, M Brylinsky and P Johnson-Green, editors]. Halifax, Canada: Atlantic Canada Society for Microbial Ecology.

Burke JL, Waghorn GC \& Brookes IM (2002) An evaluation of sulla (Hedysarum coronarium) with pasture, white clover and lucerne for lambs. New Zealand Society of Animal Production 62, 152-156.

Cheeke PR (1998) Natural Toxicants in Feeds, Forages and Poisonous Plants. Danville, IL: Interstate Publishers Inc.

Cremin JD, Drackley JK, Hansen LR, Grum DF, Odle J \& Fahey GC (1995) Effects of glycine and bovine serum albumin on inhibition of propionate metabolism in ovine hepatocytes caused by reduced phenolic monomers. Journal of Animal Science 73, 3009-3021.

Douglas GB, Stienezen M, Waghorn GC \& Foote AG (1999) Effect of condensed tannins in birdsfoot trefoil (Lotus corniculatus) and sulla (Hedysarum coronarium) on body weight, carcass fat depth, and wool growth of lambs in New Zealand. New Zealand Journal of Agricultural Research 42, 55-64.

Foo LY, Lu Y, McNabb WC, Waghorn GC \& Ulyatt MJ (1997) Proanthocyanidins from Lotus pedunculatus. Phytochemistry 45, 1689-1696.

Foo LY, Newman R, Waghorn GC, McNabb WC \& Ulyatt MJ(1996) Proanthocyanidins from Lotus corniculatus. Phytochemistry 41, 617-624.

Grabber JH, Ralph J \& Hatfield RD (1998) Ferulate cross-links limit the enzymatic degradation of synthetically lignified primary walls of maize. Journal of the Science of Food and Agriculture 77, 193-200.

Grundhofer P, Niemetz R, Schilling G \& Cross GG (2001) Biosynthesis and subcellular distribution of hydrolysable tannins. Phytochemistry 57, 915-927.

Harris SL, Clark DA \& Labuyrie PJ (1998) Birdsfoot trefoil - an alternative legume for New Zealand dairy pastures. Proceedings of the New Zealand Grassland Association 60, 99-103.

Hatfield RD, Jung HG, Ralph J, Buxton DR \& Weimer PJ (1994) A comparison of the insoluble residues produced by the Klason lignin and detergent lignin procedures. Journal of the Science of Food and Agriculture 65, 51-58.

Hatfield RD, Ralph J \& Grabber JH (1999) Cell wall structural foundations: molecular basis for improving forage digestibilities. Crop Science 39, 27-37.

Hoskin SO, Wilson PR, Barry TN, Charleston WAG \& Waghorn GC (2000) Effect of forage legumes containing condensed tannins on lungworm (Dictyocaulus sp.) and gastrointestinal parasitism in young red deer (Cervus elaphus). Research in Veterinary Science 68, 223-230.

Jones RJ, Meyer JHF, Bechaz FM, Stultz MA, Palmer B \& Van der Merwe G (2001) Comparison of rumen fluid from South African game species and from sheep to digest tanniniferous browse. Australian Journal of Agricultural Research 52, 453-460.

Jung HG (1989) Forage lignins and their effects on fibre digestibility. Agronomy Journal 81, 33-38.

Jung HG, Mertens DR \& Payne AJ (1997) Correlation of acid detergent lignin and Klason lignin with digestibility of forage dry matter and neutral detergent fibre. Journal of Dairy Science $\mathbf{8 0}$, $1622-1628$.

Larkin PJ, Tanner GJ, Joseph RG \& Kelman WM (1999) Modifying condensed tannin content in plants. In Proceedings of the XVIII International Grasslands Congress, vol. 3, pp. 167-178 [JG Buchanan-Smith, LD Bailey and P McCaughey, editors]. Calgary, Alta: Association Management Centre.

Leathwick DM \& Atkinson DS (1995) Dagginess and flystrike in lambs grazed on Lotus corniculatus or ryegrass. Proceedings of the New Zealand Society of Animal Production 55, 196-198.

Lowry JB, Conlan LL, Schlink AC \& McSweeney CS (1994) Acid detergent dispersible lignin in tropical grasses. Journal of the Science of Food and Agriculture 65, 41-49.

Lowry JB, McSweeney CS \& Palmer B (1996) Changing perceptions of the effect of plant phenolics on nutrient supply in the ruminant. Australian Journal of Agricultural Research 47, 829-842.

Lowry JB, Sumpter EA, McSweeney CS, Schline AC \& Bowden B (1993) Phenolic acids in the fibre of some tropical grasses, effect on feed quality and their metabolism by sheep. Australian Journal of Agricultural Research 44, 1123-1133.

McMahon LR, McAllister TA, Berg BP, Majak W, Acharya SN, Popp JD, Coulman BE, Wang Y \& Cheng K-J (2000) A review of the effects of forage condensed tannins on ruminal fermentation and bloat in grazing cattle. Canadian Journal of Plant Science 80, 469-485.

McNabb WC, Waghorn GC, Peters JS \& Barry TN (1996) The effect of condensed tannins in Lotus pedunculatus on the solubilisation and degradation of ribulose-1,5-bisphosphate carboxylase (EC 4.1.1.39; Rubisco) protein in the rumen and the sites of Rubisco digestion. British Journal of Nutrition 76, 535-549.

Min BR, McNabb WC, Barry TN, Kemp PD, Waghorn GC \& McDonald MF (1999) The effect of condensed tannins in Lotus corniculatus upon reproductive efficiency and wool production in sheep during late summer and autumn. Journal of Agricultural Science, Cambridge 132, 323-334.

Molan AL, Waghorn GL \& McNabb WC (2002) Effect of condensed tannins on egg hatching and larval development of Trichostrongylus colubriformis in vitro. Veterinary Record $\mathbf{1 5 0}$, 65-69.

Molan AL, Waghorn GC, Min BR \& McNabb WC (2000) The effect of condensed tannins from seven herbages on Trichostrongylus colubriformis larval migration in vitro. Folia Parasitologica 47, 39-44.

Mueller-Harvey I (2001) Analysis of hydrolysable tannins. Animal Feed Science and Technology 91, 3-20.

Mueller-Harvey I \& McAllan AB (1992) Tannins. Their biochemistry and nutritional properties. In Advances In Plant Cell Biochemistry And Biotechnology, vol. 1, pp. 151-217 [IM Morrison, editor]. London: JAI Press Ltd.

Niezen JH, Charleston WAG, Robertson HA, Shelton D, Waghorn GC \& Green R (2000a) The effect of feeding sulla (Hedysarum coronarium) or lucerne (Medicago sativa) on lamb parasite burdens and development of immunity to gastrointestinal parasites. Veterinary Parasitology 105, 229-245.

Niezen JH, Waghorn TS, Charleston WAG \& Waghorn GC (1995) Growth and gastrointestinal nematode parasitism in lambs grazing either lucerne (Medicago sativa) or sulla (Hedysarum coronarium) which contains condensed tannins. Journal of Agricultural Science, Cambridge 125, 281-289. 
Niezen JH, Waghorn GC, Graham T, Carter JL \& Leathwick DM (2002b) The effect of diet fed to lambs on subsequent development of Trichostrongylus colubriformis larvae in vitro and on pasture. Veterinary Parasitology 105, 269-283.

Ortiz LT, Alzueta C, Trevino J \& Castano M (1994) Effects of faba bean tannins on the growth and histological structure of the intestinal tract and liver of chicks and rats. British Poultry Science 35, 743-754.

Palm CA \& Sanches PA (1991) Nitrogen release from the leaves of some tropical legumes as affected by their lignin and polyphenolic contents. Soil Biology and Biochemistry 23, 83-88.

Priolo A, Waghorn GC, Lanza M, Biondi L \& Pennisi P (2000) Polyethylene glycol as a means for reducing the impact of condensed tannins in Carob pulp: Effects on lamb growth performance and meat quality. Journal of Animal Science 78, $810-816$.

Reed JD (1995) Nutritional toxicology of tannins and related polyphenols in forage legumes. Journal of Animal Science 73, $1516-1528$.

Rittner U \& Reed JD (1992) Phenolics and in vitro degradability of protein and fibre in west African browse. Journal of the Science of Food and Agriculture 58, 21-28.

Robertson HA, Niezen JH, Waghorn GC, Charleston WAG \& Jinlong M (1995) The effect of six herbages on liveweight gain wool growth and faecal egg count of parasitised ewe lambs. Proceedings of the New Zealand Society of Animal Production 55, 199-201.

Satter LD, Jung HG, Van Vuuren AM \& Engels FM (1999) Challenges in the nutrition of high producing ruminants. In Nutritional Ecology Of Herbivores. Proceedings of the Vth International Symposium on the Nutrition of Herbivores, pp. 609-646 [HG Jung and GC Fahey Jr, editors]. Savoy, IL: American Society of Animal Science.

Scalbert A (1991) Antimicrobial properties of tannins. Phytochemistry 30, 3875-3883.

Taylor CE \& Murant AF (1966) Nematicidal activity of aqueous extracts from raspberry canes and roots. Nematologica 12, 488-494.

Terrill TH, Rowan AM, Douglas GB \& Barry TN (1992) Determination of extractable and bound condensed tannin concentrations in forage plants. Protein concentrate meals and cereal grains. Journal of the Science of Food and Agriculture 58, 321-329.

Terrill TH, Waghorn GC, Woolley DJ, McNabb WC \& Barry TN (1994) Assay and digestion of ${ }^{14} \mathrm{C}$-labelled condensed tannins in the gastrointestinal tract of sheep. British Journal of Nutrition $\mathbf{7 2}$, 467-477.

Waghorn GC (1996) Condensed tannins and nutrition absorption from the small intestine. In Proceedings of the 1996 Canadian Society of Animal Science Annual Meeting, pp. 175-194 [LM Rode, editor]. Lethbridge, Alta: Lethbridge Research Centre.
Waghorn GC (2002) Can forages match concentrate diets for dairy production? Proceedings of the New Zealand Society of Animal Production 62, 261-266.

Waghorn GC, Adams NR \& Woodfield DR (2002a) Deleterious substances in grazed pastures. In Sheep Nutrition, pp. 333-356 [M Freer and $\mathrm{H}$ Dove, editors]. Wallingford, Oxon: $\mathrm{CAB}$ International.

Waghorn GC, Gregory NG, Todd SE \& Wesselink R (1999a) Dags in sheep; a look at faeces and reasons for dag formation. Proceedings of the New Zealand Grassland Association 61, 43-49.

Waghorn GC, Reed JD \& Ndlovu LR (1999b) Condensed tannins and herbivore nutrition. In Proceedings of the XVIIth International Grasslands Congress, vol. 3, pp. 153-156 [JG Buchanan-Smith, LD Bailey and D McCaughey, editors]. Calgary, Alta: Association Management Centre.

Waghorn GC \& Shelton ID (1997) Effect of condensed tannins in Lotus corniculatus on the nutritive value of pasture for sheep. Journal of Agricultural Science, Cambridge 128, 365-372.

Waghorn GC, Shelton ID \& Thomas VJ (1989) Particle breakdown and rumen digestion of fresh ryegrass (Lolium perenne L.) and Lucerne (Medicago sativa L.) fed to cows during a restricted feeding period. British Journal of Nutrition 61, 409-423.

Waghorn GC, Tavendale MH \& Woodfield DR (2002b) Methanogenesis from forages fed to New Zealand ruminants Proceedings of the New Zealand Grassland Association 64, 167-171.

Walton JP, Waghorn GC, Plaizier JC, Birtles M \& McBride BW (2002) Influence of condensed tannins on gut morphology in sheep fed Lotus pedunculatus. Canadian Journal of Animal Science 81, 605-607.

Wang Y, Douglas GB, Waghorn GC, Barry TN \& Foote AG (1996a) The effect of condensed tannins in Lotus corniculatus upon the lactation performance in ewes. Journal of Agricultural Science, Cambridge 126, 353-362.

Wang Y, Waghorn GC, McNabb WC, Barry TN, Hedley MJ \& Shelton ID (1996b) Effect of condensed tannins in Lotus corniculatus upon the digestion of methionine and cysteine in the small intestine of sheep. Journal of Agricultural Science, Cambridge 127, 413-421.

Wilson JR (1993) Organization of forage plant tissues. In Forage Cell Wall Structure And Digestibility, pp. 1-32 [H Jung, D Buxton, R Hatfield and J Ralph, editors]. Madison, WI: American Society of Agronomy Inc.

Wilson JR \& Hatfield RD (1997) Structural and chemical changes of cell types during stem development: consequences for fibre degradation by rumen microflora. Australian Journal of Agricultural Research 48, 165-180.

Woodward SL, Auldist MJ, Laboyrie PJ \& Jansen EBL (1999) Effect of Lotus corniculatus and condensed tannins on milk yield and milk composition of dairy cows. Proceedings of the New Zealand Society of Animal Production 54, 152-155. 